Article

\title{
Poly(4-vinylpyridinium) perchlorate as an efficient and recyclable catalyst for the synthesis of biscoumarins and bisindoles
}

\author{
Farhad Shirini*, Saeed Esmaeeli-Ranjbar, Mohadeseh Seddighi \\ Department of Chemistry, Faculty of Sciences, University of Guilan, Rasht 41335, Iran
}

\section{A R T I C L E I N F O}

Article history:

Received 14 November 2013

Accepted 3 January 2014

Published 20 July 2014

\section{Keywords:}

Poly(4-vinylpyridinium) perchlorate

Biscoumarins

Bis(indolyl)methanes

Reusable catalyst

\begin{abstract}
A B S T R A C T
Poly(4-vinylpyridinium) perchlorate has been used as an efficient solid acid catalyst for the synthesis of 3,3'-(arylmethylene)bis(4-hydroxycoumarins) and bis(indolyl)methanes, with the products being formed in excellent yields over very short reaction times under mild and environmentally friendly conditions. This catalyst can be reused several times without any appreciable loss in its activity.
\end{abstract}

(C) 2014, Dalian Institute of Chemical Physics, Chinese Academy of Sciences. Published by Elsevier B.V. All rights reserved.

tions. Cross-linked poly(vinylpyridine) (PVPy) is one of the most commonly used heterogeneous polymeric supports in organic chemistry, where it has been used as a support for numerous reagents and catalysts because of its commercial availability, stability, high loading capacity, good swelling characteristics, and good physicochemical properties, as well as the ease with which it can be functionalized [1]. PVPy has also been recognized as an attractive support for the immobilization of mineral acids because of the basic nature of its pyridine groups, and a variety of different PVP-supported reagents have been designed in this context to catalyze a range of organic reactions [2-5].

Heterocyclic compounds are widely distributed in nature and are essential to life. Coumarins, in particular, are an important class of heterocyclic compounds that have been incorporated into a wide variety of therapeutic agents in the pharmaceutical industry because they exhibit a wide range of biological properties such as anti-bacterial [6], anti-HIV [7], anti-Hepatitis C [8], antitumor [9], and anticancer [10] activity. Biscoumarins, which are the bridged substituted dimers of

\footnotetext{
* Corresponding author. Tel/Fax: +98-131-3233262; E-mail: shirini@guilan.ac.ir 
coumarin, have also been used as anti-inflammatory, anticoagulant, antipyretic, antifungal, anticoagulant, and antiseptic agents [11,12], as well as urease inhibitors [13]. 3,3'-Arylmethylene-bis-4-hydroxycoumarins are an important class of biscoumarins that are derived from the condensation of aldehydes with 4-hydroxycoumarin, and a variety of different catalysts and reagents have been developed to facilitate this reaction [12-20].

Indoles represent another important class of heterocyclic compounds because of their broad range of biological activity [21]. Among them, bis(indolyl)alkane derivatives have been the subject of considerable levels of interest because of their numerous applications in pharmaceutical and biological research, where they have been reported to show antitumor [22], antileishmanial [23], antihyperlipidemic [24], and anticancer [25] activity. In light of their potential therapeutic applications, the development of new strategies and methodologies for the synthesis of these compounds continues to attract significant levels of interest from synthetic organic chemists. One of the simplest and most straightforward methods reported for the synthesis of bis(indolyl)methanes [26-28] involves the condensation of aldehydes with indoles, and a variety of catalysts, including $\mathrm{I}_{2}$ [29], sulfamic acid [30], benzyltriphenylphosphonium tribromide [31], ceric ammonium nitrate [32], [hmim] $\mathrm{HSO}_{4}$ acidic ionic liquid [33], zirconyldodecylsulfate [34], $\mathrm{ZrOCl}_{2} \cdot 8 \mathrm{H}_{2} \mathrm{O}$,

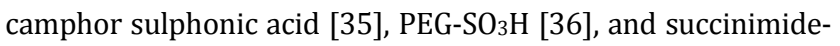
$N$-sulfonic acid (SuSA) [37], have been reported for this reaction.

Although these procedures generally provide efficient access to the coumarin and indole structures, many of these catalysts and activators suffer from disadvantages such as their requirement for long reaction times, harsh reaction conditions, and the use of large excesses of toxic reagents. Furthermore, most of these catalysts cannot be recovered and reused. Based on these limitations, there is therefore an urgent need for the development of a simple, efficient, and mild procedure for the synthesis of compounds belonging to these structural classes involving the use of a recyclable solid catalyst system that can be readily separated from the reaction mixture and reused without any discernible loss in its activity.

\section{Experimental}

\subsection{General}

All the chemicals used here were purchased from Merck, Aldrich, and Fluka and used without further purification. The reaction products were characterized on the basis of their physical properties and through a comparison with authentic samples. The reactions were monitored by thin layer chromatography (TLC) using silica gel SIL G/UV 254 TLC plates (Germany). Infrared (IR) spectra were recorded on a Perkin Elmer 781 spectrophotometer (Germany). ${ }^{1} \mathrm{H}$ NMR spectra were recorded on a Bruker Avance $400 \mathrm{MHz}$ instrument (Germany) and the ${ }^{13} \mathrm{C}$ NMR data were collected on a Bruker Avance $100 \mathrm{MHz}$ instrument. All the chemical shifts from the NMR spectra have been reported relative to TMS using deuterated solvent. Melt- ing points were recorded on a Büchi B-545 apparatus (Germany) in open capillary tubes.

\subsection{General procedure for the synthesis of biscoumarin derivatives}

A mixture of 4-hydroxycoumarin (2 mmol), aldehyde (1 mmol), Poly(4-vinylpyridinium) perchlorate ([P(4-VPH)ClO 4 , poly(4-vinylpyridine) cross-linked with 2\% DVB, $\sim 60$ mesh, MW 60000; Fluka) (30 mg), and water ( $5 \mathrm{~mL}$ ) was placed in a round-bottomed flask and heated at $80{ }^{\circ} \mathrm{C}$. Upon completion of the reaction, as determined by TLC analysis, the mixture was cooled to room temperature and filtered, and the filter-cake was washed with ethanol $(10 \mathrm{~mL})$ to give the catalyst. Water was then added to the filtrate until precipitation occurred, and the resulting solid was collected by filtration to give the desired product in high purity. The spectral data of the new compounds are shown below.

Compound 1m. ${ }^{1} \mathrm{H} \mathrm{NMR}\left(\mathrm{CDCl}_{3}, 400 \mathrm{MHz}\right): \delta=2.50(3 \mathrm{H}, \mathrm{s}$, $\left.\mathrm{CH}_{3}\right), 6.08(1 \mathrm{H}, \mathrm{s}, \mathrm{CH}), 7.16(2 \mathrm{H}, \mathrm{d}, J=8.0 \mathrm{~Hz}), 7.23(2 \mathrm{H}, \mathrm{d}, J=8.4$ $\mathrm{Hz}), 7.39-7.45(4 \mathrm{H}, \mathrm{m}), 7.6\left(2 \mathrm{H}, \mathrm{td}, J_{1}=7.6 \mathrm{~Hz}, J_{2}=1.6 \mathrm{~Hz}\right)$, 8.02-8.11 (2H, m), $11.34(1 \mathrm{H}, \mathrm{s}, \mathrm{OH}), 11.55(1 \mathrm{H}, \mathrm{s}, \mathrm{OH})$.

Compound 1r. ${ }^{1} \mathrm{H}$ NMR (DMSO-d $\left.6,400 \mathrm{MHz}\right): \delta=6.43(1 \mathrm{H}, \mathrm{s}$, $\mathrm{CH}), 7.26(2 \mathrm{H}, \mathrm{t}, J=7.6 \mathrm{~Hz}), 7.3(2 \mathrm{H}, \mathrm{d}, J=8.0 \mathrm{~Hz}), 7.56\left(2 \mathrm{H}, \mathrm{td}, J_{1}\right.$ $\left.=7.6 \mathrm{~Hz}, J_{2}=1.2 \mathrm{~Hz}\right), 7.82\left(2 \mathrm{H}, \mathrm{dd}, J_{1}=7.8 \mathrm{~Hz}, J_{2}=1.2 \mathrm{~Hz}\right), 7.94$ $\left(1 \mathrm{H}, \mathrm{td}, J_{1}=7.0 \mathrm{~Hz}, J_{2}=2.0 \mathrm{~Hz}\right), 8.37(1 \mathrm{H}, \mathrm{d}, J=8.0 \mathrm{~Hz}), 8.66(1 \mathrm{H}$, s), $8.72(1 \mathrm{H}, \mathrm{d}, J=5.2 \mathrm{~Hz}), 16.93(\mathrm{bs}, \mathrm{OH}) ;{ }^{13} \mathrm{C}$ NMR (DMSO-d6, $100 \mathrm{MHz}): \delta=35.1,102.9,116.2,119.9,123.6,124.6,127.1$, 132.0, 139.5, 140.7, 143.3, 145.3, 153.2, 164.5, 168.5 .

Compound 1s. ${ }^{1} \mathrm{H}$ NMR (DMSO-d $\left.6,400 \mathrm{MHz}\right): \delta=6.49(1 \mathrm{H}, \mathrm{s}$, $\mathrm{CH}), 7.23(2 \mathrm{H}, \mathrm{t}, J=7.2 \mathrm{~Hz}), 7.28(2 \mathrm{H}, \mathrm{d}, J=8.4 \mathrm{~Hz}), 7.5(2 \mathrm{H}, \mathrm{t}, J=$ $7.2 \mathrm{~Hz}), 7.81-7.83(4 \mathrm{H}, \mathrm{m}), 8.6(2 \mathrm{H}, \mathrm{d}, J=6 \mathrm{~Hz}), 16.97(\mathrm{bs}, \mathrm{OH})$; ${ }^{13} \mathrm{C}$ NMR (DMSO-d6, $100 \mathrm{MHz}$ ): $\delta=38.3,101.8,116.1,119.8$, 123.5, 124.6, 125.7, 131.8, 141.2, 153.2, 164.6, 165.6, 168.6.

\subsection{General procedure for the synthesis of bis(indolyl)methane derivatives}

A mixture of aldehyde ( $1 \mathrm{mmol})$, indole $(2 \mathrm{mmol})$, and [P(4-VPH) $\left.\mathrm{ClO}_{4}\right](30 \mathrm{mg})$ was vigorously mixed with a pestle and mortar at room temperature, and produced a syrup-like material that solidified on standing. Upon completion of the reaction (as determined by TLC), ethanol (10 $\mathrm{mL}$ ) was added to the mixture to precipitate the catalyst, which was collected by filtration. Water was then added to the filtrate until precipitation occurred, and the resulting solid was collected by filtration to give the desired product in high purity. The spectral data for the new compounds are shown below.

Compound 2r. ${ }^{1} \mathrm{H}$ NMR (DMSO-d $6,400 \mathrm{MHz}$ ): $\delta=3.58(6 \mathrm{H}, \mathrm{s}$, $\left.\mathrm{OCH}_{3}\right), 5.94(1 \mathrm{H}, \mathrm{s}, \mathrm{CH}), 6.7\left(2 \mathrm{H}, \mathrm{dd}, J_{1}=8.8 \mathrm{~Hz}, J_{2}=2.4 \mathrm{~Hz}\right), 6.79$ $(2 \mathrm{H}, \mathrm{d}, J=2.4 \mathrm{~Hz}), 6.89(2 \mathrm{H}, \mathrm{s}), 7.26(2 \mathrm{H}, \mathrm{d}, J=8.8 \mathrm{~Hz})$, $7.42-7.47(2 \mathrm{H}, \mathrm{m}), 7.57\left(1 \mathrm{H}, \mathrm{dd}, J_{1}=8.4 \mathrm{~Hz}, J_{2}=1.6 \mathrm{~Hz}\right)$, 7.79-7.87 (4H, m), $10.72(\mathrm{~s}, \mathrm{NH}) ;{ }^{13} \mathrm{C}$ NMR (DMSO-d 6100 $\mathrm{MHz}$ ): $\delta=55.7,101.9,111.0,112.5,117.9,124.9,125.7,126.3$, 127.5, 127.9, 128.0, 128.1, 132.2, 132.3, 133.5, 143.2, 153.2.

Compound 2s. ${ }^{1} \mathrm{H}$ NMR (DMSO- $\left.\mathrm{d}_{6}, 400 \mathrm{MHz}\right): \delta=6.50(1 \mathrm{H}, \mathrm{s}$, CH), $7.24(2 \mathrm{H}, \mathrm{s}), 7.57(2 \mathrm{H}, \mathrm{d}, J=8.8 \mathrm{~Hz}), 7.68(2 \mathrm{H}, \mathrm{d}, J=8.8 \mathrm{~Hz})$, 
$8.0\left(2 \mathrm{H}, \mathrm{dd}, J_{1}=9.0 \mathrm{~Hz}, J_{2}=2.0 \mathrm{~Hz}\right), 8.22(2 \mathrm{H}, \mathrm{d}, J=8.8 \mathrm{~Hz}), 8.40$ $(2 \mathrm{H}, \mathrm{d}, J=2.4 \mathrm{~Hz}), 11.9$ (s, NH); ${ }^{13} \mathrm{C}$ NMR (DMSO-d $\left.6,100 \mathrm{MHz}\right): \delta$ $=38.4,112.6,116.5,117.3,119.7,124.3,126.0,128.3,129.9$, 140.1, 140.8, 146.6, 152.3.

Compound 2t. ${ }^{1} \mathrm{H}$ NMR (DMSO-d $\left.6,400 \mathrm{MHz}\right): \delta=3.73(3 \mathrm{H}, \mathrm{s}$, $\left.\mathrm{OCH}_{3}\right), 6.15(1 \mathrm{H}, \mathrm{s}, \mathrm{CH}), 6.89(2 \mathrm{H}, \mathrm{d}, J=8.4 \mathrm{~Hz}), 7.12(2 \mathrm{H}, \mathrm{s})$, $7.30(2 \mathrm{H}, \mathrm{d}, J=8.8 \mathrm{~Hz}), 7.55(2 \mathrm{H}, \mathrm{d}, J=9.2 \mathrm{~Hz}), 7.98\left(2 \mathrm{H}, \mathrm{dd}, J_{1}=\right.$ $\left.9 \mathrm{~Hz}, J_{2}=2 \mathrm{~Hz}\right), 8.32(2 \mathrm{H}, \mathrm{d}, J=2.4 \mathrm{~Hz}), 11.67(\mathrm{~s}, \mathrm{NH}) ;{ }^{13} \mathrm{C} \mathrm{NMR}$ (DMSO-d6, $100 \mathrm{MHz}$ ): $\delta=38.1,55.4,112.5,114.2,116.7,117.1$, $121.4,126.2,127.8,129.6,136.1,140.2,140.6,158.1$.

\section{Results and discussion}

As part of our ongoing research into the application of solid acid catalysts in organic reactions [38-40], and in light of the growing interest in the use of indole and coumarin derivatives in medicinal chemistry, we recently became interested in investigating the use of the newly reported polymer-based solid acid catalyst [P(4-VPH)ClO 4 ] (Scheme 1) [41] for the synthesis of 3,3'-(arylmethylene)bis(4-hydroxycoumarins) and bis(indolyl)methanes.

At first, we focused our attention on the synthesis of biscoumarin compounds using the $\left[\mathrm{P}(4-\mathrm{VPH}) \mathrm{ClO}_{4}\right]$ catalyst, and the reaction between 4-nitrobenzaldehyde and 4-hydroxycoumarin to give the corresponding biscoumarin was selected as a model reaction to optimize the reaction conditions, including the amount of the catalyst, solvent, and reaction

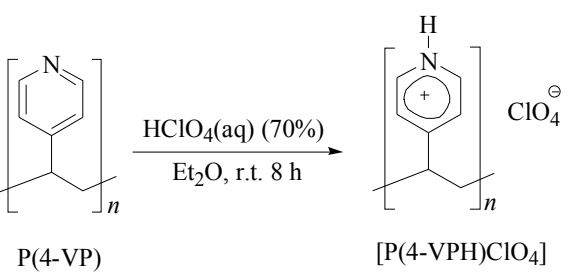

Scheme 1. Preparation of $\left[\mathrm{P}(4-\mathrm{VPH}) \mathrm{ClO}_{4}\right]$ solid acid catalyst.<smiles>[R]C(=O)[CH]Oc1cc(=O)oc2ccccc12</smiles>

Scheme 2. Synthesis of 3,3'-(arylmethylene)-bis-(4-hydroxycoumarin) derivatives in the presence of $\left[\mathrm{P}(4-\mathrm{VPH}) \mathrm{ClO}_{4}\right]$.

temperature. Several different solvents were screened against the model reaction, including dichloromethane, diethyl ether, ethanol, and water, which gave the best results in terms of the yield and reaction time. Following a period of screening, the optimal reaction conditions for the model reaction were determined to be $1 \mathrm{mmol}$ aldehyde, $2 \mathrm{mmol}$ 4-hydroxycoumarin, and $30 \mathrm{mg}$ of the $\left[\mathrm{P}(4-\mathrm{VPH}) \mathrm{ClO}_{4}\right]$ catalyst in $5 \mathrm{~mL}$ of $\mathrm{H}_{2} \mathrm{O}$ at 80 ${ }^{\circ} \mathrm{C}$, as shown in Scheme 2. It is noteworthy that further increases in the amount of catalyst or temperature did not lead to any improvements in the reaction time or yield.

Table 1

Preparation of 3,3'-(arylmethylene)-bis-(4-hydroxycoumarins) derivatives catalyzed by [P(4-VPH)ClO 4 .

\begin{tabular}{|c|c|c|c|c|c|c|}
\hline \multirow{2}{*}{ Entry } & \multirow{2}{*}{ Aldehyde } & \multirow{2}{*}{ Product } & \multirow{2}{*}{ Time (min) } & \multirow{2}{*}{ Yield (\%) } & \multicolumn{2}{|c|}{ Melting point $\left({ }^{\circ} \mathrm{C}\right)$} \\
\hline & & & & & Found & Reported \\
\hline 1 & $\mathrm{C}_{6} \mathrm{H}_{5}-$ & $1 \mathrm{a}$ & 15 & 90 & $228-230$ & $228-230[17]$ \\
\hline 2 & $2-\mathrm{ClC}_{6} \mathrm{H}_{4}-$ & 1b & 60 & 82 & $204-206$ & 201-203 [17] \\
\hline 3 & $3-\mathrm{ClC}_{6} \mathrm{H}_{4}-$ & 1c & 35 & 93 & $227-228$ & $228-230[16]$ \\
\hline 4 & $4-\mathrm{ClC}_{6} \mathrm{H}_{4}-$ & 1d & 20 & 92 & $254-256$ & $252-254[14]$ \\
\hline 5 & $4-\mathrm{BrC}_{6} \mathrm{H}_{4}-$ & $1 \mathrm{e}$ & 20 & 88 & $264-266$ & $265-267[16]$ \\
\hline 6 & $2-\mathrm{NO}_{2} \mathrm{C}_{6} \mathrm{H}_{4}-$ & 1f & 20 & 91 & $210-212$ & $200-202$ [17] \\
\hline 7 & 3- $\mathrm{NO}_{2} \mathrm{C}_{6} \mathrm{H}_{4}-$ & $1 \mathrm{~g}$ & 15 & 87 & $237-239$ & $234-236[16]$ \\
\hline 8 & $4-\mathrm{NO}_{2} \mathrm{C}_{6} \mathrm{H}_{4}-$ & $1 \mathrm{~h}$ & 15 & 95 & $233-235$ & $232-234$ [17] \\
\hline 9 & $2-\mathrm{CH}_{3} \mathrm{C}_{6} \mathrm{H}_{4}-$ & $1 \mathbf{i}$ & 45 & 89 & $216-218$ & $218-220[16]$ \\
\hline 10 & $3-\mathrm{CH}_{3} \mathrm{OC}_{6} \mathrm{H}_{4}-$ & $\mathbf{1 j}$ & 25 & 92 & $249-251$ & $238[13]$ \\
\hline 11 & $4-\mathrm{CH}_{3} \mathrm{OC}_{6} \mathrm{H}_{4}-$ & $1 \mathrm{k}$ & 55 & 89 & $250-251$ & $249-250$ [17] \\
\hline 12 & $4-\left(\mathrm{CH}_{3}\right)_{2} \mathrm{NC}_{6} \mathrm{H}_{4}-$ & 11 & 25 & 94 & $220-222$ & $222-224$ [16] \\
\hline 13 & $4-\mathrm{CH}_{3} \mathrm{SC}_{6} \mathrm{H}_{4}-$ & $1 \mathrm{~m}$ & 15 & 92 & $258-260$ & - \\
\hline 14 & $2-\mathrm{OHC}_{6} \mathrm{H}_{4}-$ & 1n & 60 & 88 & $252-254$ & $254-256$ [17] \\
\hline 15 & & 10 & 25 & 91 & $230-232$ & $230-232$ [19] \\
\hline 16 & & $1 p$ & 60 & 90 & 191-193 & $190-192$ [18] \\
\hline 17 & & 1q & 100 & 88 & $240-242$ & $240-244$ [14] \\
\hline 18 & & $1 \mathbf{r}$ & 120 & 89 & $270-272$ & $274-276[42]$ \\
\hline 19 & & $1 s$ & 60 & 91 & $271-272$ & $261-263[42]$ \\
\hline 20 & & 1t & 30 & 83 & $196-198$ & 198 [18] \\
\hline
\end{tabular}

Reaction conditions: 4-hydroxycoumarin $2 \mathrm{mmol}$, aldehyde $1 \mathrm{mmol}$, [P(4-VPH)ClO 4$] 30 \mathrm{mg}, \mathrm{H}_{2} \mathrm{O} 5 \mathrm{~mL}, 80{ }^{\circ} \mathrm{C}$. 
With the optimized conditions in hand, we proceeded to investigate the general scope and acceptability of this method using a variety of simple and readily available aldehydes (Table 1). Pleasingly, a wide range of aromatic aldehydes containing an electron-withdrawing (i.e., $\mathrm{Cl}, \mathrm{Br}$, and $\mathrm{NO}_{2}$ ) or electron-donating (i.e., $\mathrm{CH}_{3}, \mathrm{OCH}_{3}, \mathrm{~N}\left(\mathrm{CH}_{3}\right)_{2}, \mathrm{SCH}_{3}$, and $\mathrm{OH}$ ) group at the ortho, meta, or para position of their benzene ring were readily converted to the corresponding 3,3'-(arylmethylene) bis(4hydroxycoumarins) in good to excellent isolated yields over short reaction times under the optimized conditions (Table 1 , entries 1-14). The results revealed that the nature of the substituent on the aromatic ring did not have a significant effect on the yields or reaction time, although ortho substituted benzaldehydes tended to require longer reaction times because of steric hindrance (Table 1, entries 2, 9, and 14). The $\alpha, \beta$-unsaturated aldehydes cinnamaldehyde and 2-nitrocinnamaldehyde also reacted smoothly under the optimized conditions to give the corresponding products in high yields without the isomerization of a double bond (Table 1, entries 15 and 16). The optimized conditions were also successfully applied to several heterocyclic aldehydes, including indole-3-carbaldehyde, pyridine-3-carbaldehyde, and pyridine-4-carbaldehyde, as well as the aliphatic aldehyde 2-phenylpropionaldehyde, with the corresponding products being formed in good yields (Table 1, entries 17-20).

Following our successful application of $\left[\mathrm{P}(4-\mathrm{VPH}) \mathrm{ClO}_{4}\right]$ as a polymer-supported acidic catalyst for the synthesis of biscoumarins, we investigated the application of this catalyst system to the synthesis of bis(indolyl)methanes via the condensation of indoles with aldehydes. The reaction between 4-nitrobenzaldehyde and indole to give the corresponding bisindole was selected as a model reaction for this study and screened under a variety of different conditions to identify the optimum conditions for this transformation. The results revealed that the best results were obtained using a grinding method with $30 \mathrm{mg}$ of the $\left[\mathrm{P}(4-\mathrm{VPH}) \mathrm{ClO}_{4}\right]$ catalyst at room temperature under solvent-free conditions (Scheme 3).

With the optimized conditions in hand, we proceeded to investigate the scope of this method by reacting a broad range of aromatic and heterocyclic aldehydes with different indole derivatives, including indole, 2-methyl indole, 5-nitro indole, and 5-methoxy indole under the optimized conditions to give the corresponding bis(indolyl)methanes in high yields over short reaction times (Table 2). Aromatic aldehydes containing electron-withdrawing (i.e., $\mathrm{Cl}, \mathrm{Br}$, and $\mathrm{NO}_{2}$ ) or electron-donating (i.e., $\mathrm{OCH}_{3}$ and $\mathrm{OH}$ ) groups, as well as $\alpha, \beta$-unsaturated (i.e., cinnamaldehyde), polycyclic aromatic (i.e., 2-naphthaldehyde), and heterocyclic (i.e., indole-3-carbaldehyde and isatin) aldehydes, all reacted smoothly with indole in the presence of the $\left[\mathrm{P}(4-\mathrm{VPH}) \mathrm{ClO}_{4}\right]$ catalyst to give the corresponding products in good yields over short reaction times (Table 2, entries 1-13). This method was also found to be applicable to the dialdehyde

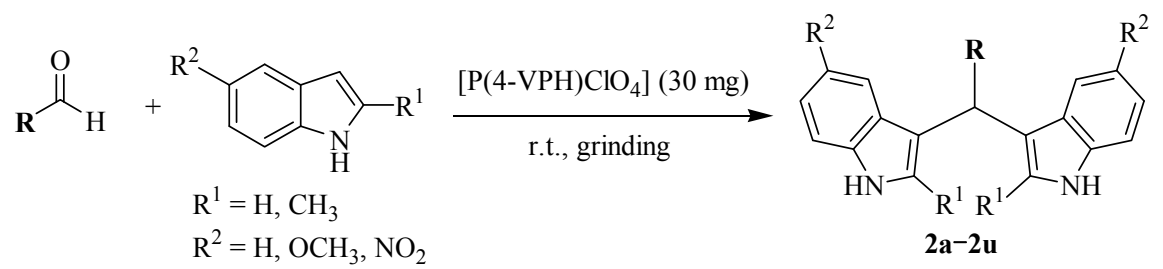

Scheme 3. Synthesis of bis(indolyl)methane derivatives in the presence of $\left[\mathrm{P}(4-\mathrm{VPH}) \mathrm{ClO}_{4}\right]$.

Table 2

Preparation of bis(indolyl)methane derivatives catalyzed by [P(4-VPH) $\left.\mathrm{ClO}_{4}\right]$.

\begin{tabular}{|c|c|c|c|c|c|c|c|c|}
\hline \multirow{2}{*}{ Entry } & \multirow{2}{*}{$\mathrm{Ar}$} & \multirow{2}{*}{$\mathrm{R}^{1}$} & \multirow{2}{*}{$\mathrm{R}^{2}$} & \multirow{2}{*}{ Product } & \multirow{2}{*}{ Time (min) } & \multirow{2}{*}{ Yield (\%) } & \multicolumn{2}{|c|}{ Melting point $\left({ }^{\circ} \mathrm{C}\right)$} \\
\hline & & & & & & & Found & Reported \\
\hline 1 & $\mathrm{C}_{6} \mathrm{H}_{5}-$ & $\mathrm{H}$ & $\mathrm{H}$ & $2 a$ & 10 & 92 & $128-130$ & $126-127$ [29] \\
\hline 2 & $2-\mathrm{ClC}_{6} \mathrm{H}_{4}-$ & $\mathrm{H}$ & $\mathrm{H}$ & $2 \mathbf{b}$ & 35 & 82 & $78-80$ & $75-76[40]$ \\
\hline 3 & $3-\mathrm{ClC}_{6} \mathrm{H}_{4}-$ & $\mathrm{H}$ & $\mathrm{H}$ & $2 c$ & 15 & 94 & $88-90$ & $83-85$ [43] \\
\hline 4 & $4-\mathrm{ClC}_{6} \mathrm{H}_{4}-$ & $\mathrm{H}$ & $\mathrm{H}$ & 2d & 8 & 89 & $78-80$ & $78-88[35]$ \\
\hline 5 & $4-\mathrm{BrC}_{6} \mathrm{H}_{4}-$ & $\mathrm{H}$ & $\mathrm{H}$ & $2 e$ & 10 & 87 & $114-116$ & $112-113$ [30] \\
\hline 6 & $2-\mathrm{NO}_{2} \mathrm{C}_{6} \mathrm{H}_{4}-$ & $\mathrm{H}$ & $\mathrm{H}$ & $2 f$ & 14 & 89 & $138-140$ & $139-141$ [36] \\
\hline 7 & $4-\mathrm{NO}_{2} \mathrm{C}_{6} \mathrm{H}_{4}-$ & $\mathrm{H}$ & $\mathrm{H}$ & $2 g$ & 7 & 92 & $222-224$ & $222-224$ [40] \\
\hline 8 & $4-\mathrm{CH}_{3} \mathrm{OC}_{6} \mathrm{H}_{4}-$ & $\mathrm{H}$ & $\mathrm{H}$ & $2 \mathrm{~h}$ & 15 & 88 & $185-186$ & $186-188$ [36] \\
\hline 9 & $4-\mathrm{OHC}_{6} \mathrm{H}_{4}-$ & $\mathrm{H}$ & $\mathrm{H}$ & $2 \mathrm{i}$ & 35 & 82 & $122-124$ & $124-125$ [44] \\
\hline 10 & $\mathrm{C}_{6} \mathrm{H}_{5}-\mathrm{CH}=\mathrm{CH}-$ & $\mathrm{H}$ & $\mathrm{H}$ & $2 \mathbf{j}$ & 25 & 89 & $178-180$ & $100-101$ [35] \\
\hline 11 & 2-Naphthyl - & $\mathrm{H}$ & $\mathrm{H}$ & $2 \mathbf{k}$ & 9 & 91 & $212-214$ & $201-203[40]$ \\
\hline 12 & 3-Indolyl - & $\mathrm{H}$ & $\mathrm{H}$ & 21 & 40 & 87 & $241-243$ & $245-247[30]$ \\
\hline 13 & Isatin & $\mathrm{H}$ & $\mathrm{H}$ & $2 m$ & 40 & 79 & $309-311$ & $>300[32]$ \\
\hline 14 & $-\mathrm{C}_{6} \mathrm{H}_{4}-$ & $\mathrm{H}$ & $\mathrm{H}$ & $2 n$ & 60 & 72 & $128-130$ & $121-123$ [29] \\
\hline 15 & $\mathrm{C}_{6} \mathrm{H}_{5}-$ & $\mathrm{CH}_{3}$ & $\mathrm{H}$ & 20 & 8 & 87 & $244-246$ & $245-247$ [36] \\
\hline 16 & $4-\mathrm{ClC}_{6} \mathrm{H}_{4}-$ & $\mathrm{CH}_{3}$ & $\mathrm{H}$ & $2 p$ & 7 & 91 & $242-244$ & $247-248[40]$ \\
\hline 17 & $4-\mathrm{CH}_{3} \mathrm{OC}_{6} \mathrm{H}_{4}-$ & $\mathrm{CH}_{3}$ & $\mathrm{H}$ & $2 q$ & 15 & 90 & $103-105$ & $102-103$ [35] \\
\hline 18 & 2-Naphthyl - & $\mathrm{H}$ & $\mathrm{OCH}_{3}$ & $2 r$ & 7 & 88 & $188-190$ & - \\
\hline 19 & $4-\mathrm{NO}_{2} \mathrm{C}_{6} \mathrm{H}_{4}-$ & $\mathrm{H}$ & $\mathrm{NO}_{2}$ & $2 s$ & 25 & 91 & $304-306$ & - \\
\hline 20 & $4-\mathrm{CH}_{3} \mathrm{OC}_{6} \mathrm{H}_{4}-$ & $\mathrm{H}$ & $\mathrm{NO}_{2}$ & $2 t$ & 20 & 89 & $317-319$ & - \\
\hline 21 & Acetophenone & $\mathrm{H}$ & $\mathrm{H}$ & $2 u$ & 120 & 0 & - & - \\
\hline
\end{tabular}

Reaction conditions: aldehyde $1 \mathrm{mmol}$, indole $2 \mathrm{mmol}$, [P(4-VPH)ClO 4$] 30 \mathrm{mg}$, grinding conditions, room temperature. 
Table 3

Comparison of the results obtained for the synthesis of 3,3'-(4-nitrophenylmethylene)-bis-(4-hydroxycoumarin) and 3,3'-(phenylmethylene)-bis(1H-indole) in the presence of $\left[\mathrm{P}(4-\mathrm{VPH}) \mathrm{ClO}_{4}\right]$ with those obtained using some of the other catalysts.

\begin{tabular}{|c|c|c|c|c|c|}
\hline Product & Catalyst (loading) & Reaction conditions & Time (min) & Yield (\%) & Ref. \\
\hline & Piperidine (a few drop) & r.t./EtOH & 240 & 96 & [13] \\
\hline & $\mathrm{I}_{2}(10 \mathrm{~mol} \%)$ & $100^{\circ} \mathrm{C} / \mathrm{H}_{2} \mathrm{O}$ & 28 & 95 & [14] \\
\hline & TBAB (10 mol\%) & $100^{\circ} \mathrm{C} / \mathrm{H}_{2} \mathrm{O}$ & 25 & 91 & [15] \\
\hline & SDS (20 mol\%) & $60^{\circ} \mathrm{C} / \mathrm{H}_{2} \mathrm{O}$ & 180 & 98 & [16] \\
\hline & {$\left[\mathrm{P}(4-\mathrm{VPH}) \mathrm{ClO}_{4}\right](30 \mathrm{mg})$} & $80{ }^{\circ} \mathrm{C} / \mathrm{H}_{2} \mathrm{O}$ & 15 & 95 & this work \\
\hline & sulfamic acid (10 mol\%) & r.t./solvent free & 30 & 92 & [30] \\
\hline & $\left(\mathrm{PhCH}_{2} \mathrm{PPh}_{3}\right)+\mathrm{Br}_{3}-/ \mathrm{SiO}_{2}(10 \mathrm{~mol} \%)$ & $90^{\circ} \mathrm{C} /$ solvent free & 16 & 80 & [31] \\
\hline & {$[\mathrm{hmim}] \mathrm{HSO}_{4}(1 \mathrm{~mol} \%)$} & r.t./EtOH & 60 & 97 & [33] \\
\hline & $\mathrm{ZrOCl}_{2} \cdot 8 \mathrm{H}_{2} \mathrm{O}(5 \mathrm{~mol} \%)$ & r.t./ $\mathrm{H}_{2} \mathrm{O}: \mathrm{EtOH}$ & 180 & 93 & [35] \\
\hline $\mathrm{HN}^{-1}$ & SuSA (5 mol\%) & r.t. $/ \mathrm{CH}_{3} \mathrm{CN}$ & 45 & 96 & [37] \\
\hline & $\mathrm{Mn} / \mathrm{ZrO}_{2}-450(20 \mathrm{mg})$ & $50^{\circ} \mathrm{C} /$ solvent free & 45 & 95 & [43] \\
\hline & $\mathrm{FeCl}_{3}-\mathrm{RiH}(150 \mathrm{mg})$ & $80^{\circ} \mathrm{C} / \mathrm{EtOH}$ & 15 & 92 & [40] \\
\hline & {$\left[\mathrm{P}(4-\mathrm{VPH}) \mathrm{ClO}_{4}\right](30 \mathrm{mg})$} & r.t./grinding & 10 & 92 & this work \\
\hline
\end{tabular}

Table 4

Reusability of $\left[\mathrm{P}(4-\mathrm{VPH}) \mathrm{ClO}_{4}\right]$ in the synthesis of biscoumarins and bisindoles.

\begin{tabular}{lccccc}
\hline \multirow{2}{*}{ Run } & \multicolumn{3}{c}{$3,3^{\prime}-$-(4-nitrophenylmethylene) bis(4-hydroxycoumarin) $(1 \mathrm{~h})$} & & \multicolumn{2}{c}{ 3,3'-(4-Nitrophenylmethylene) bis(1H-indole) (2 g) } \\
\cline { 2 - 3 } \cline { 5 - 6 } Time (min) & Yield (\%) & 95 & Time (min) & 92 \\
2 & 15 & 95 & 7 & 91 \\
3 & 15 & 92 & 8 & 89 \\
4 & 17 & 92 & 10 & 88 \\
5 & 19 & 90 & 14 & 89 \\
\hline
\end{tabular}

terephthaldialdehyde, which reacted successfully with four equivalents of indole to give di-bis(indolyl)methane in good yield (Table 2, entry 14). 2-Methyl indole, 5-methyl indole, and 5-nitro indole were also successfully converted to the corresponding bis(indolyl)methanes under the optimized conditions (Table 2, entries 15-20). It is clear from the results that indoles bearing an electron-donating substituent (i.e., $\mathrm{CH}_{3}$ and $\mathrm{OCH}_{3}$ ) were converted to the desired products over a shorter reaction time than indoles bearing an electron-withdrawing substituent (i.e., $\mathrm{NO}_{2}$ ). Furthermore, the application of the optimized reaction conditions to ketones such as acetophenone did not result in any reaction, which highlighted the chemoselectivity of the current protocol towards aldehydes, which are more reactive than ketones because of their higher electrophilicity (Table 2, entry 21).

To highlight the merits of our newly developed procedures, we have compared our results for the synthesis of 3,3'-(4-nitrophenylmethylene)-bis-(4-hydroxycoumarin) and 3,3'(phenylmethylene)-bis-(1H-indole) using the [P(4-VPH)ClO $\left.{ }_{4}\right]$ catalyst with the results of several other catalytic systems reported in the literature for the same transformation. As shown in Table 3, the newly developed methods avoid some of the disadvantages associated with the other procedures such as long reaction time, harsh reaction conditions, toxic reagents, high temperature, organic solvents, large excesses of reagents, and low yields.

The reusability of the catalyst was also evaluated for both types of reaction. Briefly, the model reactions were studied under the optimized reaction conditions. Upon completion of the reactions, the catalyst was separated by filtration, washed with diethyl ether, dried under vacuum, and used again in the same reaction. This process was repeated over five runs for each type of reaction, and the results showed that the reactions proceeded efficiently to give the desired products without any significant changes in yield of the products. These results therefore clearly demonstrated the practical recyclability of the $\left[\mathrm{P}(4-\mathrm{VPH}) \mathrm{ClO}_{4}\right]$ catalyst (Table 4).

It is noteworthy that most of the bis(indolyl)methane and biscoumarin derivatives were highly colored compounds. The colors of some of these compounds are shown in Fig. 1.

\section{Conclusions}

$\left[\mathrm{P}(4-\mathrm{VPH}) \mathrm{ClO}_{4}\right]$ has been used as a powerful solid acid catalyst for the simple and efficient synthesis of bis(indolyl)methane and biscoumarin derivatives. There are several advantages to the current procedure over existing catalytic systems, such as high reaction rates, ease of preparation and handling of the catalyst, simple and green experimental procedures, and use of an inexpensive and reusable catalyst. Furthermore, this process avoids the problems associated with the use of organic solvents, high temperatures and liquid acids, and therefore represents an attractive synthetic strategy for the synthesis of bis(indolyl)methane and biscoumarin derivatives from an economic and environmental perspective.

\section{Acknowledgments}

We are thankful to the University of Guilan Research Council for the partial support of this work. 

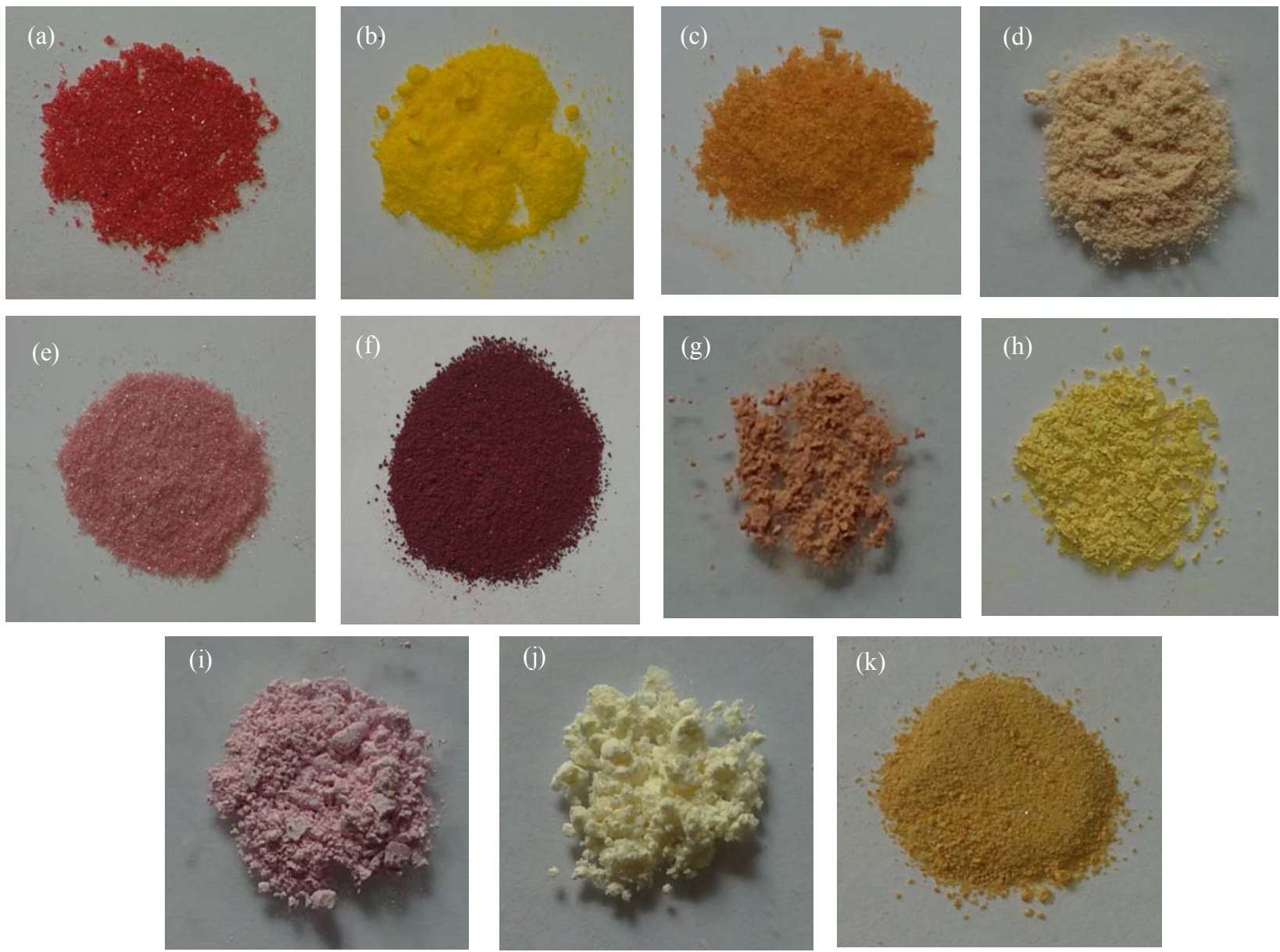

Fig. 1. The colors of some of the bis(indolyl)methane and biscoumarin derivatives. (a) Indole $+4-\mathrm{Br}$ benzaldehyde; (b) Indole $+2-\mathrm{NO}_{2}$ benzaldehyde; (c) Indole+Indole-3-carbaldehyde; (d) Indole+Isatin; (e) 2-Methylindole+benzaldehyde; (f) 2-Methylindole+4-Cl benzaldehyde; (g) 5-Methoxyindole+2-naphthaldehyde; (h) 5-Nitroindole $+4-\mathrm{CH}_{3} \mathrm{O}$ benzaldehyde; (i) Coumarin $+4-\left(\mathrm{CH}_{3}\right)_{2} \mathrm{~N}$-benzaldehyde; (j) Coumarin $+4-\mathrm{CH}_{3} \mathrm{~S}$ benzaldehyde; $(\mathrm{k})$ Coumarin+2-Nitro cinnamaldehyde.

\section{References}

[1] Tamami B, Borujeni K P. Iran Polym J, 2009, 18: 191

[2] Herrman W A, Kratzer R M, Blümel J, Friedrich H B, Fischer R W, Apperley D C, Mink J, Berkesi O. J Mol Catal A, 1997, 120: 197

[3] Tamami B, Hatam M, Mohadjer D. Polymer, 1991, 32: 2666

[4] Albadi J, Keshavarz M, Shirini F, Vafaie-nezhad M. Catal Commun, 2012, 27: 17

[5] Khaligh N G, Shirini F. J Mol Catal A, 2011, 348: 20

[6] Kong Y, Fu Y J, Zu Y G, Chang F R, Chen Y H, Liu X L, Stelten J, Schiebel H M. Food Chem, 2010, 121: 1150

[7] Zhou P, Takaishi Y, Duan H, Chen B, Honda G, Itoh M, Takeda Y, Kodzhimatov O K, Lee K H. Phytochemistry, 2000, 53: 689

[8] Neyts J, De Clercq E, Singha R, Chang Y H, Das A R, Chakraborty S K, Hong S C, Tsay S C, Hsu M H, Hwu J R. J Med Chem, 2009, 52 : 1486

[9] Ito C, Itoigawa M, Onoda S, Hosokawa A, Ruangrungsi N, Okuda T, Tokuda H, Nishino H, Furukawa H. Phytochemistry, 2005, 66: 567

[10] Bhattacharyya S S, Paul S, Mandal S K, Banerjee A, Boujedaini N, Khuda-Bukhsh A R. Eur J Pharmacol, 2009, 614: 128

[11] Hussain H, Hussain J, Al-Harrasi A, Krohn K. Tetrahedron, 2012, 68: 2553

[12] Manolov I, Maichle-Moessmer C, Danchev N. Eur J Med Chem, 2006, 41: 882
[13] Khan K M, Iqbal S, Lodhi M A, Maharvi G M, Ullah Z, Choudhary M I, Rahman A, Perveen S. Bioorg Med Chem, 2004, 12: 1963

[14] Kidwai M, Bansal V, Mothsra P, Saxena S, Somvanshi R K, Dey S, Singh T P.J Mol Catal A, 2007, 268: 76

[15] Khurana J M, Kumar S. Tetrahedron Lett, 2009, 50: 4125

[16] Mehrabi H, Abusaidi H.J Iran Chem Soc, 2010, 7: 890

[17] Tavakoli-Hoseini N, Heravi M M, Bamoharram F F, Davoodnia A, Ghassemzadeh M. J Mol Liq, 2011, 163: 122

[18] Tabatabaeian K, Heidari H, Khorshidi A, Mamaghani M, Mahmoodi N 0.J Serb Chem Soc, 2012, 77: 407

[19] Das Gupta A, Samanta S, Mondal R, Mallik A K. Bull Korean Chem Soc, 2012, 33: 4239

[20] Niknam K, Jamali A. Chin J Catal (催化学报), 2012, 33: 1840

[21] Sharma V, Kumar P, Pathak D.J Heterocyclic Chem, 2010, 47: 491

[22] Diana P, Carbone A, Barraja P, Martorana A, Gia O, DallaVia L, Cirrincione G. Bioorg Med Chem Lett, 2007, 17: 6134

[23] Bharate S B, Bharate J B, Khan S I, Tekwani B L, Jacob M R, Mudududdla R, Yadav R R, Singh B, Sharma P R, Maity S, Singh B, Khan I A, Vishwakarma R A. Eur J Med Chem, 2013, 63: 435

[24] Sashidhara K V, Kumar A, Kumar M, Srivastava A, Puri A. Bioorg Med Chem Lett, 2010, 20: 6504

[25] Kamal A, Srikanth Y V V, Ramaiah M J, Khan M N A, Reddy M K, Ashraf M, Lavanya A, Pushpavalli S N C V L, Pal-Bhadra M. Bioorg Med Chem Lett, 2012, 22: 571

[26] Xu H Y, Zi Y, Xu X P, Wang S Y, Ji S J. Tetrahedron, 2013, 69: 1600 


\section{Graphical Abstract}

Chin. J. Catal., 2014, 35: 1017-1023 doi: 10.1016/S1872-2067(14)60061-9

Poly(4-vinylpyridinium) perchlorate as an efficient and recyclable catalyst for the synthesis of biscoumarins and bisindoles

Farhad Shirini*, Saeed Esmaeeli-Ranjbar, Mohadeseh Seddighi

University of Guilan, Iran

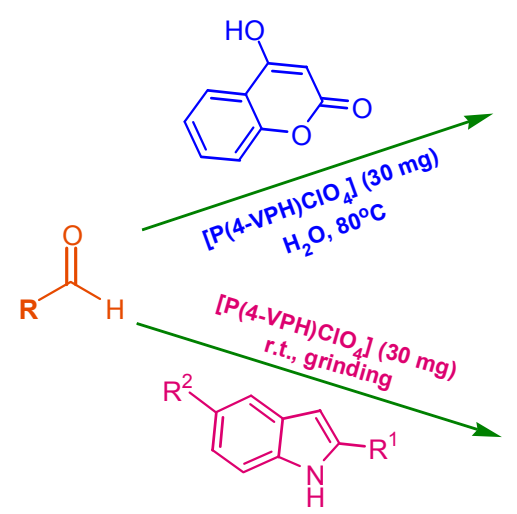<smiles>[R]C(c1c(O)c2ccccc2oc1=O)c1c(O)c2ccccc2oc1=O</smiles><smiles>[R]c1ccc2[nH]c([R])c(C([R])c3c([R])[nH]c4ccc([R])cc34)c2c1</smiles>

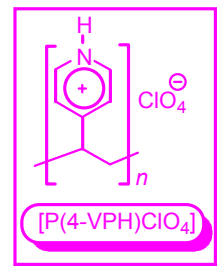

A mild, simple, and efficient procedure has been developed for the synthesis of 3,3'-(arylmethylene)-bis-(4-hydroxy coumarins) and bis(indolyl)methanes using poly(4-vinylpyridinium) perchlorate $\left[\mathrm{P}(4-\mathrm{VPH}) \mathrm{ClO}_{4}\right]$ as an efficient heterogeneous catalyst.

[27] Ke B, Qin Y, He Q F, Huang Z Y, Wang F P. Tetrahedron Lett, 2005, 46: 1751

[28] Zeng X F, Ji S J, Wang S Y. Tetrahedron, 2005, 61:10235

[29] Ji S J, Wang S J, Zhang Y, Loh T P. Tetrahedron, 2004, 60: 2051

[30] An L T, Ding F Q, Zou J P, Lu X H, Zhang L L. Chin J Chem, 2007, 25: 822

[31] Shirini F, Langroodi M S, Abedini M. Chin Chem Lett, 2010, 21: 1342

[32] Wang S Y, Ji S J. Tetrahedron, 2006, 62: 1527

[33] Gu D G, Ji S J, Jiang Z Q, Zhou M F, Loh T P. Synlett, 2005: 959

[34] Jafarpour M, Rezaeifard A, Golshani T. J Heterocyclic Chem, 2009, 46: 535

[35] Mishra S, Ghosh R. Indian J Chem B, 2011, 50B: 1630
[36] Hasaninejad A, Shekouhy M, Zare A, Ghattali S M S H, Golzar N. J Iran Chem Soc, 2011, 8: 411

[37] Shirini F, Khaligh N G. Chin J Catal (催化学报), 2013, 34: 1890

[38] Shirini F, Mamaghani M, Seddighi M. Catal Commun, 2013, 36: 31

[39] Shirini F, Jolodar O G.J Mol Catal A, 2012, 356: 61

[40] Shirini F, Akbari-Dadamahaleh S, Mohammad-Khah A. C R Chim, 2013, 16: 945

[41] Khaligh N G.J Mol Catal A, 2012, 363: 90

[42] Manolov I, Maichle-Moessmer C, Nicolova I, Danchev N. Arch Pharm Chem Life Sci, 2006, 339: 319

[43] Rekha M, Manjunath H R, Nagaraju N. J Ind Eng Chem, 2013, 19: 337

[44] Nagawade R R, Shinde D B. Acta Chim Slov, 2006, 53: 210 